\title{
Mechanical Characterization and Assessment of the CMS Conductor
}

\author{
S. Sequeira Tavares, A. Calvo, A. Desirelli, S. Sgobba CERN, Geneva, Switzerland \\ I. Horvath, ETH-Zürich, Switzerland
}

\begin{abstract}
The Compact Muon Solenoid (CMS) is one of the experiments which are being designed in the framework of the Large Hadron Collider (LHC) project at CERN. The design field of the CMS magnet is $\mathbf{4} \mathrm{T}$, the magnetic length is $12.5 \mathrm{~m}$ and the free aperture is $6 \mathrm{~m}$ in diameter. This is achieved with a 4 layer and 5 module superconducting Alstabilized coil, resulting into 20 lengths of conductor of $2.5 \mathrm{~km}$ ench, energized at a nominal current of $20 \mathrm{kA}$ at 4.5 K. One of the unique features of this thin solenoid is an Al-stabilized conductor reinforced by an Al-alloy, An extensive characterization of mechanical properties at room temperature and $4.2 \mathrm{~K}$ has been carried out in order to define the most appropriate alloy and temper for the reinforcement. The effect of the coil curing cycle on the alloy properties has been taken into account. This paper surnmarizes the main rcsults of these tests.
\end{abstract}

\section{INTRODUCTION}

The conductor design consists of four parts: a central flat superconducting cable, a high purity aluminum (Al 99.998\%) stabilizer (called together the "insert") and two external Aluminum Alloy (AA) reinforcing sections (Fig. 1) [1]. The main characteristics of the CMS conductot are reported in [2].

The reinforcing sections, which will be Electron Beam (EB) welded to the insert in a continuous process [2], are aimed to withstand electromechanical forces. The CMS coil will consist of 20 wound lengths of finished conductor, each $2.55 \mathrm{~km}$ long. The cross-section of the tcinforcement to be welded will be $24.0_{-0.2}^{+0.2} \mathrm{~mm} \times 18.0_{-0.2}^{+0.2} \mathrm{~mm}$. The finished conductor will be machined after welding to a cross-section of $64.0_{-0.2}^{+0.0} \mathrm{~mm} \times 21.7_{-0.5}^{+0.5} \mathrm{~mm}$.

The state of stress of the conductor coil was calculated by Finitc Element Analysis (FEA) for the two main operating conditions; coil at $4.5 \mathrm{~K}$ and cnergized coil at $4.5 \mathrm{~K}$. The maximum Von Mises stress in the AA (occurring in the energized coil) is estimated to be $115-145 \mathrm{MPa}$. The maximum shear stress in the energized coil, at the interface pure Al/ AA, is estimated to be $8 \mathrm{MPa}$ [3]. Since the pure aluminum has poor mechanical properties the reinforcement sections will confer the necessary strength.

\footnotetext{
Manuscrijt received September 27, 1999.

S. Sequeira Tavares is with Engineering Suppost and Technologies Divisjon, CERN - European Laboratory for Pntticle Physics, CH-1211 Genavi 23, Switzerland (Phone: +4122767 3234, Fix: +41 227673350 , e-majl: Sandra,Sequeira,Tayares@ern.ch).
}

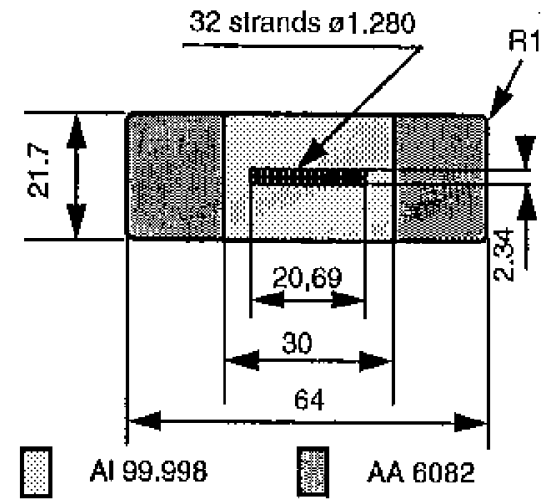

Fig. 1. Cross-section of the conductor:

A curing cycle will be applied to the insulating resin that will cover the magnet coil after winding and impregnation. Temperature and time at temperature during the curing cycle (up to $29 \mathrm{~h}$ at $135^{\circ} \mathrm{C}$, see $\$$ III B.) might affect the properties of the reinforcement (antealing or aging).

\section{Selection of the Alloy, Temper and Fabrication METHOD}

Several high strength aluminum alloys and tempers have been considered as candidates for application as a reinforcement: EN AW-6082-T6 (typical extrusion alloy, showing high strength in precipitation hardened states even improving at low temperature, and high toughness at low temperature); EN AW-5083 (readily weldable alloy, also by EB, has poor strength in as-fabricated state or solution annealed states: it can be hardened only by strain); EN AW-2219 T8x (highly resistant precipitation-hardenable alloy, readily weldable, is not easily obtainable in Europe).

Operational EB weldability studies between the high purity aluminum conductor and the reinforcement [4] lead to the choice of the aluminum alloy EN AW-6082 for the reinforcement. This choice was supported by discussions with European AA producers, Continuous coiled lengths of the retained grade might be abricated by two different production methods.

1. The first consists of a continuous billet-on-billet extrusion process with an on-line quench from the extrusion temperature. Since EN AW-6082 undergoes natural aging and in order to avoid dispersion of the mechanical properties, an artificial aging treatment (underaging) has been foreseen. Tho temper associated with this fabrication method is suggested to be referred to as T51 cooled from an elcvated temperature shaping 
process and artificially underaged to a substantial stable conclition, in order to improve formability) according to the standard EN $515^{1}$. Underaging is specified as at artificial aging aimed to stabilize the tensile properties to spccified values and resulting after the curing cycle in a further overall increase of the tensile yield strength.

2. The other possible production method consists of a continuous casting process followed by several rolling operations and on-line solution quenching. The final dimensions would be achieved through cold working (strain hardening) by transforming a circular section into a square one. Finally, the resulting section would undergo natural aging. This production method would result in a final temper of the $\mathrm{T} 3$ or $\mathrm{T} 4$ type, i.c. in a product solution heat trcated, cold worked, and naturally aged to a stbstantially stable condition or a product solution heat treated and naturally aged to a substantially stable condition, respectively. This fabrication method has not been considered at this stage since respect of dimensional tolctances and achievement of required mechanical properties were not guaranteed.

\section{EXPERIMENTAL}

In order to evaluate and compare the tensile and notch tensile properties of the atoy EN AW-6082 in different tempers, a test campaign was carried out at room temperature (RT) and at $4.2 \mathrm{~K}$ (at CERN and at Air Liquide, respectively).

\section{A. Matcrial}

Different batches of EN AW-6082 have been considered: 1. EN AW-6082-T6; cxtruded bat from supplicr $X$.

2. As-extruded EN AW-6082; section issued from a coil representative of a continuous extrusion, from supplier $\mathrm{Y}$ (supply $\mathrm{Y}-1$ ).

3. EN AW-6082-T51; as in point 2. but artificially underaged, from supplier Y (supply Y-2).

The chemical composition range of EN AW-6082, as defined in the standard EN 573-3, as well as the chemical compositions of the products delivered by supplicrs $X$ and $Y$ are shown in Table I.

The bar from supplier $X$ is a standardized product, delivered in T6 temper (solution heat treated and artificially aged) and used in this campaign as a reference product. The sections coming from supplier $Y$ (supply $Y-1$ in the as-extruded state and supply $\mathrm{Y}-2$ in $\mathrm{T} 51$ temper) were produced by a dedicated continuous extrusion, through a billet-on-billet process. The extrusion temperature was approximately $540^{\circ} \mathrm{C}$, the extrusion speed $8 \mathrm{~m} / \mathrm{min}$ and the quenching rate around $12^{\circ} \mathrm{C} / \mathrm{s}$, Spooling was done simultaneously with the extrusion.

\footnotetext{
I All the cited temper designations are according to EN 515
}

\section{B. Additional Treatments}

A thermal cycle reproducing the curing applied on the wound magnet ( $\mathrm{Fig} .2$ ), called from here on "curing cycle", was simulated on machined specimens, when applicable, in at air fumace.

\section{Tensile and Notch Tensile Testing}

Tensile tests and notch tensile tests were carricd out at RT and at $4.2 \mathrm{~K}$, on specimens machined longitudinally from the extruded bar and sections. Tensile testing was performed on specimens with a diameter of $12.7 \mathrm{~mm}$ and a gauge length of $50 \mathrm{~mm}$. The specimens for the notch tensile testing wore of the same dimensions as the tensile specimens, apart from a $V$-notch machined at the center of the gauge length (Fig. 3). The ratio of the Notch Tensile Strength (NTS) to the $0.2 \%$ offset tensile yicld strength $\left(R_{1}, 0.2\right)$ is a significant comparative index of plane-strain fracture toughness [5].

TABLE I

CHLMICAL COMLOSTLION OF TESTED EN AW-6082 PRODUCTS

\begin{tabular}{cccc}
\hline Elcment & $\begin{array}{c}\text { Stnndard } \\
\text { FN 573-3 } \\
(\text { min-max) }\end{array}$ & Supplier X & Supplitr Y \\
\hline Si & $0.7-1.3$ & 0.748 & 1.14 \\
Fe & 0.50 & 0.185 & 0.17 \\
Cu & 0.10 & 0.066 & 0.07 \\
Mo & $0.40-1.0$ & 0.440 & 0.50 \\
Mg & $0.6-I .2$ & 0.637 & 0.78 \\
Cr & 0.25 & 0.137 & 0.15 \\
Zn & 0.20 & 0.043 & 0.019 \\
Ti & 0.10 & 0.012 & 0.017 \\
Al & remaining & temaining & Rcmaining \\
\hline
\end{tabular}

Nominal chemical composition of the atloy EN AW-6082, according to the standard EN 573-3, and analyzed composition of products from suppliers $X$ ind $Y$ (wt $\%$ ).

"Single values represent the maximum allowed contant.

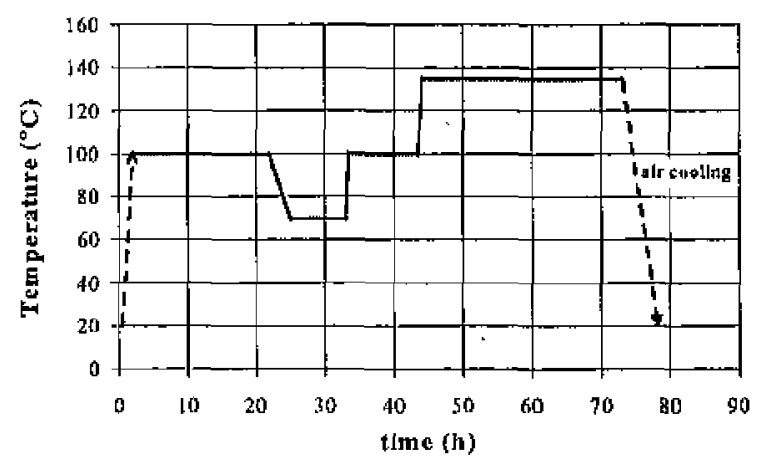

Fig, 2, Curing cycle: $20 \mathrm{~h}$ at $100^{\circ} \mathrm{C}, 170^{\circ} \mathrm{C}$ in $3 \mathrm{~h} ; 8 \mathrm{~h}$ at $70^{\circ} \mathrm{C} ; 1100^{\circ} \mathrm{C}$ in $30 \mathrm{~min} ; 10 \mathrm{~h}$ at $100^{\circ} \mathrm{C}$; $1135^{\circ} \mathrm{C}$ in $30 \mathrm{~min} ; 29$ at $135^{\circ} \mathrm{C}$; air ccoling. 


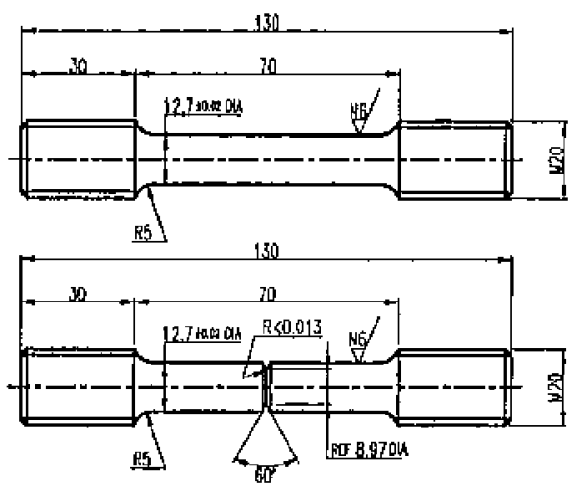

Frg. 3. Tensile and notch tensile design of the specimens. The design of the notch tensile specimens was done nccording to ASTM E 602-91.

Testing at RT was performed at CERN, on an universal electromechanical testing machinc, UTS 200.4 (load cell $200 \mathrm{kN}$ ) equipped with an optical extensometer, UTS 411.01 (resolation $0.3 \mu \mathrm{m}$, accuracy grade I, according to EN 10002). In the elastic range the applied stressing rate was $10 \mathrm{~N} \cdot \mathrm{mm}^{-2} \cdot \mathrm{s}^{-1}$ while in the plastic range the applicd straining rate was $3.3 \cdot 10^{-3} \mathrm{~s}^{-1}$. Tests at $4.2 \mathrm{~K}$ were performed at Air Liquide, on a hydraulic tensile testing machine, INSTRON 8502 (load cell $250 \mathrm{kN}$ ) using a MTS extensometer (type 632.11 C 21). The tests were carried out inside a specially designed liquid helium cryostat. The stressing rate was $23.3 \mathrm{~N} \cdot \mathrm{mm}^{-2} \cdot \mathrm{s}^{-1}$ in the clastic regime and the straining rate was $1.0 \cdot 10^{-3} \mathrm{~s}^{-1}$ in the plastic regime.

\section{ResulTS}

Results ate summarized in Figures 4 and 5 and in Table II. Tensile properties at RT, for the as-received states (T6, as-extruded and T51) and after a curing cycle are reported. Properties at $4.2 \mathrm{~K}$ for the as-received states are also shown. The reference grade and temper EN AW-6082-T6 has the highest tensile strength $\left(R_{t i t}\right)$ and $R_{p 0.2}$ at $R T$ and the lowest values of total clongation at fracture $\left(\mathrm{A}_{\mathrm{t}}<17 \%\right)$. At $4.2 \mathrm{~K}$, a significant average increase of $R_{p 0.2}(+46 \%)$ and $R_{m}(+88 \%)$ compared to RT properties, is observed.

The effect of the curing cycle on RT propertics is irrelevant for the T6 temper, ats expected, while it is particularly important for temper T51. Curing applied to the temper T51 results in an increase of yicld and tensile strength to values compatable to the temper $T 6$ NTS/R $_{p 02}$ at $4.2 \mathrm{~K}$ always exceds 1.4 for all the states.

For $12.7 \mathrm{~mm}$ diameter samples this value should correspond to a high resistance to plane-strain fracture ofiginated from crack or crack-like discontinuities (if compared to the value 1.3 as quoted in [6]). The highest values of NTS/ $R_{p} 0.2$ are measured for as-extruded state and T51 temper.
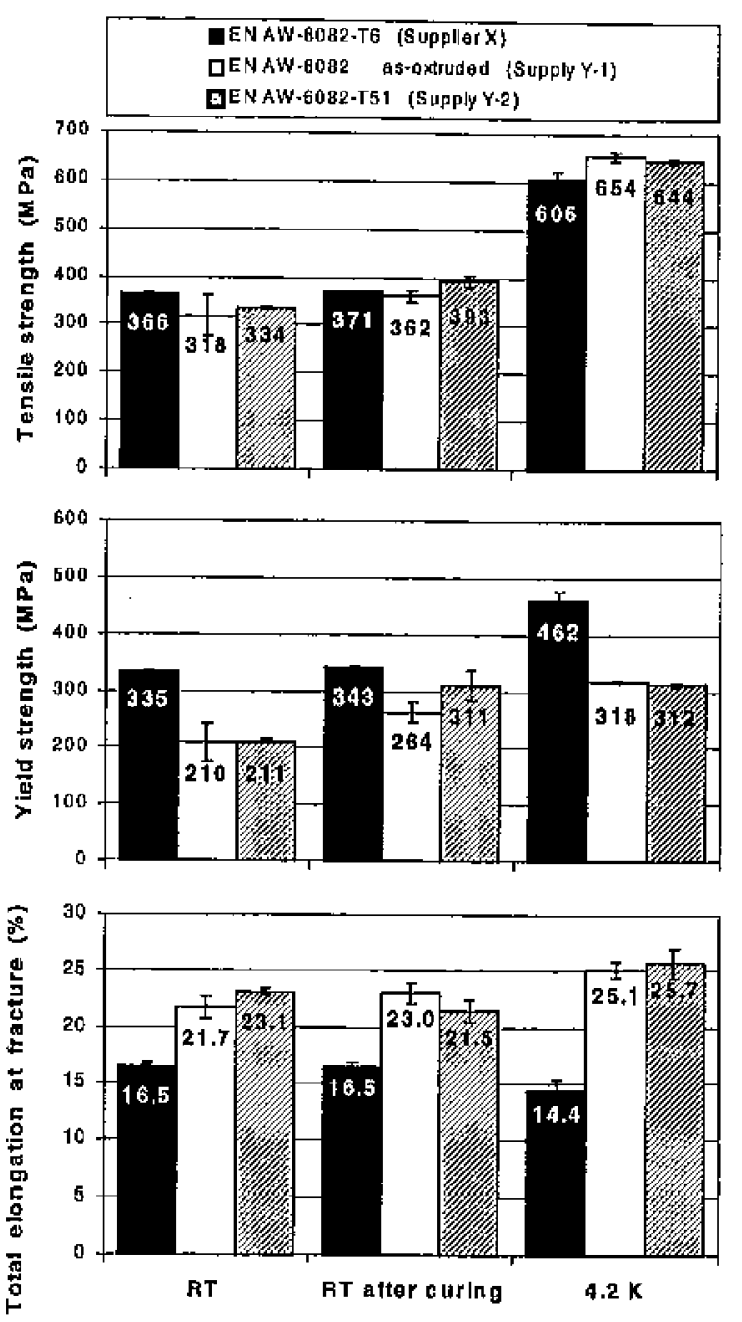

Fig. 4. Tensile propertics of EN AW-6082, in different tenper states.

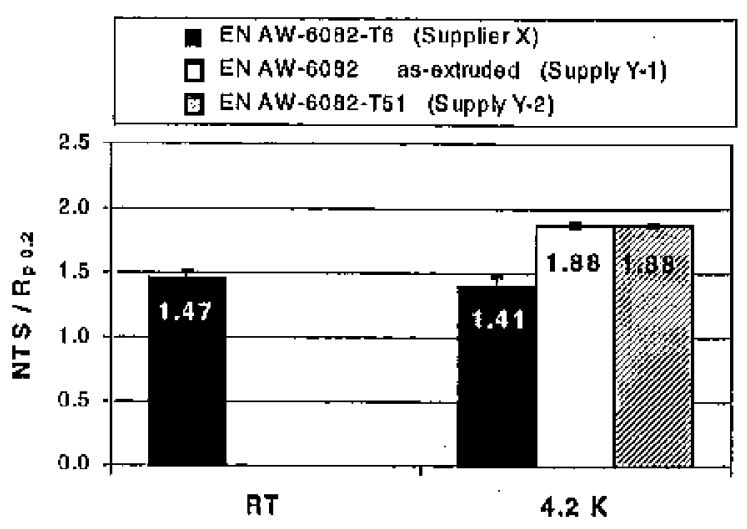

Fig. 5. Notch tensile strength over yiald strength, 
TARLE II

SUMMARY OF TIE TENSILL PROPERTIFS OF BN AW-6082, IN DIIHERENT TEMPER STATLS, AT ROOM TLMPERATURE AND AT $4.2 \mathrm{~K}$

\begin{tabular}{|c|c|c|c|c|}
\hline & $\begin{array}{l}\text { Mechanical } \\
\text { Properties }\end{array}$ & $\begin{array}{c}\text { RT } \\
\text { as-received }\end{array}$ & $\begin{array}{l}\text { RT' after } \\
\text { curlng cycle }\end{array}$ & $\begin{array}{c}4.2 \mathrm{~K} \\
\mathrm{~ns}-\mathrm{reccived}\end{array}$ \\
\hline \multirow{5}{*}{ 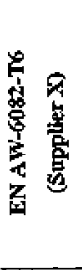 } & $\mathrm{R}_{\mathrm{m}}(\mathrm{MPa})$ & $366 \pm 1$ & $371 \pm 1$ & $606 \pm 15$ \\
\hline & $R_{\mathrm{Na}_{2}}(\mathrm{MPa})$ & $335 \pm 2$ & $343 \pm 2$ & $462 \pm 13$ \\
\hline & $A_{1}(\%)$ & $16.5 \neq 0.2$ & $16.5 \pm 0.3$ & $14.4 \pm 1.0$ \\
\hline & $\operatorname{NTS}(\mathrm{MPa})$ & $491 \pm 13$ & - & $650 \pm 18$ \\
\hline & $\mathrm{NTS} / \mathbf{R}_{\mathrm{pu}, \mathrm{a}}$ & $1.47 \pm 0.04$ & - & $1.41 \pm 0.07$ \\
\hline \multirow{5}{*}{ 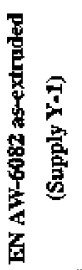 } & $\mathrm{R}_{\mathrm{m}}$ (MPa) & $318 \pm 4 \mathrm{l}$ & $362 \pm 13$ & $654 \pm 10$ \\
\hline & $\mathrm{R}_{\mathrm{Fa}, 2,2}(\mathrm{MP} \cdot \mathrm{a})$ & $210 \pm 35$ & $264 \pm 17$ & $318 \pm 2$ \\
\hline & $A_{1}(\%)$ & $21.7 \pm 1.0$ & $23.0 \pm 0.9$ & $25.1 \pm 0.7$ \\
\hline & NTS (MPa) & - & - & $597 \pm 4$ \\
\hline & NTS / $R_{p 0.2}$ & - & - & $1,88 \pm 0,02$ \\
\hline \multirow{5}{*}{ 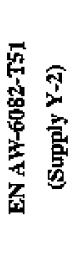 } & $\mathrm{R}_{\mathrm{n}}(\mathrm{MPa})$ & $334 \pm 3$ & $393 \pm 11$ & $644 \pm 6$ \\
\hline & $\mathrm{R}_{\mathrm{pa}, 2}(\mathrm{MPa})$ & $211 \pm 4$ & $311 \pm 26$ & $3: 2 \pm 3$ \\
\hline & $A_{1}(\%)$ & $23.1 \pm 0.3$ & $21.5 \pm 1,0$ & $25.7 \pm 1.3$ \\
\hline & NTS (MPa) & - & - & 586 \\
\hline & NTS $/ R_{\mathrm{p} n, 2}$ & - & - & $1.88 \pm 0.01$ \\
\hline
\end{tabular}

\section{DISCUSSION}

The temper T6 corresponds to the peak aging propertics for the precipitation hardening alloy EN AW-6082. Minimum tensile properties of extruded bars of EN AW-6082-T6 are guaranteed by international standards (c.g. EN 755.2 guarantees $R_{p} 0.2>250 \mathrm{MPr}$ and $R_{1 n}>295 \mathrm{MPa}$ ). The values measured in this paper at RT for the $T 6$ temper $\left(R_{p 0.2}=335 \mathrm{MPa}\right.$ and $\left.R_{m}=366 \mathrm{MPa}\right)$ fulfill the standard requirements. Tensile and yield strength of $\mathrm{T} 6$ temper increase considerably at cryogenic temperature, Values measured at $4.2 \mathrm{~K}$ are higher compared to the values cited in literature for a similar grade and temper, EN AW-6061-T6 $\left(R_{p} 0.2=379 \mathrm{MPa}\right.$ and $R_{m}=483 \mathrm{MPa}$ ), while $N T S / R_{p 0,2}$ is lower (l,4l vs, 1,63 ). As for EN AW-6061-T6, NTS/R 0.2 of EN AW-6082-T6 does not significantly decrease with decreasing temperature [7].

However, it is not possible to fabricate a continuously extruded coiled product in a T6 temper by a billet-on-billet process. Continuous quenching cannot be performed in the portions of the extrusion surrounding the region of change of billet. On the other hand, guenching the entire extruded coil is not easily achieved due to the size of the coil itself and limitations of furnace size.

Unlike T6, T5I temper is industrially applicable to a continuously extruded coil, since it simply requires quenching from extrusion temperature and final artificial underaging. The tensile properties of the T51 temper at RT after a curing cycle increase up to values comparable to the typical ones of the T6 temper. In addition, T51 temper shows higher values of elongation and, at $4.2 \mathrm{~K}$, higher plane-strain fracture toughness than T6 temper.

\section{Conclusions}

EN AW-6082 is a readily extrudable alloy, easily weldable by EB in hetcrogencous assemblies with pure Al, Its tensile properties at R'T and at $4.2 \mathrm{~K}$ make it a good candidate alloy for the reinforcement of the CMS superconducting cable.

The T5t temper corresponds to satisfactory tensile propertics and will withstand the stresses calculated by FEA. Moreover, this temper would represent a double advantage compared to a T6 temper:

1. lower tensile properties in the underaged state will facilitate spooling, despooling and winding operations;

2. the curing cycle applied on the wound magnet will confer to the reinforcement final tensile propertics which approach the ones of a peak-aged product.

The results of the campaign of testing performed at RT and at $4.2 \mathrm{~K}$ confirm that tensile properties of the EN AW-6082-T51 are compatible, in terms of resistance to Von Mises stresses, with the requirements for the reinforcement of the CMS conductor.

\section{ACKNOWLEDGMENT}

The authors acknowledge Air Liquide for performing the tensile and notch tensile tests at $4.2 \mathrm{~K}$.

\section{REFERENCES}

[1] A. Hervs, "The CMS detector magnet," subtnitted to this conference.

[2] I. Horvath, B. Dardel, H. P. Marti, J. Nutenschwander, R. Smith, P. Fabbricatore, R. Musenich, A. Calvo, D. Campi, B. Curé, A. Desitelli, G. Favee, P. L. Riboni, S. Sgobba, T. Tardy, and 5. Sequeira Tavares, "The CMS conductor", submitted to this conferences.

[3] A. Desirelui, A. Calvo, P. Fabbricatore, S. Farinon, B. Levesy, and C. Pes, "FE stress analysis of the CMS ungenet coil." subruitted to this conference

[4] Raphael Naoux, "Selection und welding propertios of in electron beam welded aluminum alloy for the reinforcement of the conductor of the CMS manct," CERN EST-SM-MB intermal report.

[5] Kaufman et al., "Notch yield ratios as a qua]ity control index for plants surain fracture toughness," Cracks and Fracture, ASTM STP 60l, Aln. Soc. Testing Mats., 1976.

[6] ASTM 602-9t, "Standard test method for sharp-notch tension testing with cylindrical speciments."

[7] Kaufman et al., "Tensile properties and notch toughness of ahuminum alloys at $-452^{\circ} \mathrm{F}$ in liquid helium, Advances in Crogenicas Engineerimg Materials, vol, 13, pp.294-308, 1968. 